DOI: https://doi.org/10.18371/fp.3(39).2020.215166

УДК 336.671

\title{
МЕТОДОЛОГІЧНІ АСПЕКТИ ПОБУДОВИ СИСТЕМИ ЕКОНОМІЧНОЇ БЕЗПЕКИ ФОРМУВАННЯ ІНВЕСТИЦІЙНОГО ПОТЕНЦІАЛУ АГРАРНОГО ПІДПРИЕМСТВА
}

\author{
БОРОВІК Любов Володимирівна \\ д.е.н., дочент, \\ дочент кафедри економіки та фінансів \\ ДВНЗ «Херсонський державний аграрний університет» \\ ORCID ID: http://orcid.org/0000-0001-7200-0497 \\ e-mail:lyubovborovik2015@gmail.com
}

\begin{abstract}
Анотація $У$ статті розглянуті питання методології побудови економічної безпеки формування інвестиційного потенціалу аграрного підприємства. Визначено принциипи системи економічної безпеки формування інвестиційного потенціалу аграрного підnриємства, яка повинна бути скерованою на досягнення як короткострокових, так $і$ середньо та довгострокових иілей.

Ключові слова: аграрне підприємство, економічна безпека, конкурентоспроможність, інвестиційний потенціал, ризики, загрози.
\end{abstract}

Постановка проблеми. Економічна та соціальна кризи, а також наслідки коронавірусної пандемії негативно вплинули в останні роки на розвиток аграрних підприємств. Загальний стан сільського господарства характеризується спадом виробництва продукції, незадовільним використанням ресурсного потенціалу товаровиробниками, низьким рівнем платоспроможності аграрних підприємств, відтоком робочої сили з сільських територій. У цій, непростій, економічній ситуації назріла потреба в удоскона-
Аннотация. B статье рассмотрены вопросы методологии построения экономической безопасности формирования инвестиционного потенциала аграрного предприятия. Определены принципы системы экономической безопасности формирования инвестиционного потенииала аграрного предприятия, которая должна быть направленной на достижение как краткосрочных, так и средне и долгосрочных ичелей.

Ключевые слова: аграрное предприятие, экономическая безопасность, конкурентность, инвестиционный потенцииал, риски, угрозы.

лені теоретичної бази побудови системи економічної безпеки формування інвестиційного аграрних підприємств та оновлення парадигми їх економічного розвитку.

Аналіз останніх досліджень і публікацій. Проблема впливу економічної безпеки на розвиток аграрних підприємств досліджувалася такими вченими як С.В. Васильчак, А.В. Крушинська, Ю.Я. Лузан, В.С. Лучик, О.М. Ляшенко, М.О. Мікуліна, O.О. Непочатенко, В.П.Синчак, І.В. Сідельникова та ін. 
Метою статті $є$ дослідження методологічних основ побудови економічної безпеки формування інвестиційного потенціалу аграрного підприємства.

Виклад основного матеріалу. Важливою умовою розвитку сільського господарства $\epsilon$ формування системи економічної безпеки аграрного підприємства, яка покликана забезпечити сталість економічного зростання аграрного сектору шляхом:

-розширеного відновлення ресурсного потенціалу аграрних підприємств;

-забезпечення екологічності технологій виробництва продукції;

-підвищення конкурентоспроможності суб'єктів виробничої діяльності на основі впровадження інноваційних технологій, які здатні забезпечити випуск продукції з високою доданою вартістю;

-попередження та ліквідації загроз, які постійно виникають у процесі виробництва та перешкоджають підвищенню продуктивності праці та зниженню собівартості продукції в аграрному секторі економіки;

-прискорення внутрішньогалузевої та аграрно-промислової кооперації й інтеграції, як фактору більш раціонального використання технічного та трудового ресурсів;

-формування інвестиційного потенціалу, здатного забезпечити розширене відтворення економічного ресурсу сільськогосподарських підприємств.

Побудова економічної безпеки формування інвестиційного потенціалу аграрного підприємства повинна відповідати принципам безперервності та цілеспрямованості, відповідати економічним завданням розвитку галузі й соціальним запитам суспільства, а також базуватись на таких загальних ме- тодологічних принципах як абстрагування, аналіз, узагальнення, індукція, дедукція, аналогія, пріоритетність, моделювання [1]. Ці, та інші, принципи дають змогу дослідити не тільки систему економічної безпеки як чогось цілого, а й кожен елемент цієї системи, що дасть можливість здійснювати ефективне управління нею.

Побудова методологічної основи системи економічної безпеки формування інвестиційного потенціалу підприємства також повинна спиратися на такі важливі принципи як системність, законність, відкритість, реалістичність, плановість, динамічність, гнучкість, автономність, інноваційність що передбачає визначення реальних цілей цієї системи та врахування особливостей аграрного виробництва, які характеризуються складністю відновлення природного потенціалу, сезонністю виробництва основних видів продукції та великими фінансовими витратами на іiі зберігання і реалізацію. Тому використання земельних і водних ресурсів, організація товарного виробництва, відновлення родючості орної землі, залежність отримання прибутку аграрного підприємства від погоднокліматичних умов, зберігання виробленої продукції потребує особливої системи захисту товаровиробників від загроз та ризиків втрати ними значної частини доходу, що може призвести до банкрутства підприємства, або ж значного скорочення робочих місць [2]. Отже, побудова системи економічної безпеки формування інвестиційного потенціалу аграрного підприємства повинна враховувати не тільки фінансово-економічні фактори, а й еколого-соціальні, що і визначає особливості вибору цілей системи захисту 
галузі від внутрішніх та зовнішніх загроз.

Система економічної безпеки формування інвестиційного потенціалу аграрного підприємства повинна бути скерованою на досягнення як короткострокових так і середньо та довгострокових цілей. Її побудова повинна грунтуватися на:

- аналізі економічної, фінансової та інвестиційної діяльності підприємства у попередньому та поточному періодах;

- дослідженні умов зовнішнього та внутрішнього інвестиційного середовища та кон'юнктури розвитку інвестиційного ринку;

- виборі моделі системи економічної безпеки формування інвестиційного потенціалу 3 урахуванням стратегічних цілей інвестиційного розвитку підприємства;

- формуванні системи економічного захисту підприємства від внутрішніх i зовнішніх загроз за основними напрямами економічної та інвестиційної діяльності підприємства;

- узгодженості взаємодії усіх елементів механізму системи економічної безпеки формування інвестиційного потенціалу у відповідності до завдань, методів, видів та напрямів економічної та інвестиційної діяльності підприємства;

- розробці системи заходів економічної безпеки формування інвестиційного потенціалу у відповідності до стратегії інвестиційного розвитку аграрного підприємства.

Розробляючи методологію побудови системи економічної безпеки формування інвестиційного потенціалу у стратегічній перспективі інвестиційного розвитку аграрного підприємства, необхідно, щоб вона відповідала таким принципам як цілеспрямованість, узгодженість, динамічність, гнучкість, інформаційність та ін., на чому наголошували такі дослідники як I.В. Демченко, Т.Б. Кузенко, Л.С. Мартюшева, О.Ю. Литовченко, К.С. Горячева, Т.В. Муляр, О.М. Петрук, C.3. Мошенський, О.М. Кардаш. Також сучасна методологія повинна передбачати принцип трансформації розвитку аграрного сектору економіки, тобто поступовий перехід від парадигми сталого до парадигми зростаючого розвитку сільського господарства [3]. Поступовому переходу аграрного сектору економіки на інноваційноінвестиційну модель свого розвитку сприятимуть процеси глобалізації та інтеграції у світовому економічному середовищі, а також поява нових методів дослідження та нових теорій. Інноваційні інформаційно-комунікаційні технології, у сучасному світі, стають стимуляторами появи глобальних виробничо-збутових зв'язків та сприяють виникненню не тільки нових професій, а й цілих галузей економіки. Це дає підстави стверджувати, що вже сьогодні назріла потреба удосконалення методів наукових досліджень проблем економічної безпеки розвитку сільського господарства [4]. Одним 3 таких методологічних підходів до пізнання напрямів розвитку суспільного господарства $\epsilon$ «синергетика», назва якої походить від грецького слова synrgos (суспільний).

Методологічні основи синергнетики, як явища, були започатковані такими дослідниками як Т. Хакеп, С. Капіца, С. Курдюков, Е. Стенгерс, а ідеї синергетики, які можуть використовуватись у вирішенні проблем економічної безпеки розвитку сільського господарства, були відображені у нау- 
кових

працях

В. Арнольда,

Л. М'яснікова, Д. Чернавського та ін.

У сучасному світі зміни у глобальній економічній системі відбуваються настільки швидко, що для аналізу й прогнозування (наприклад, розвитку інвестиційних ринків) потрібен синтез нових аналітичних методів, джерелами яких можуть бути різні сфери людських знань. Наприклад, такий синтез був здійснений на межі теорії складності та теорії синергетики, які досліджують причини виникнення нових структур і систем, що дозволяє прогнозувати вірогідні зміни у поведінці окремих систем та побудувати механізми економічної безпеки їх розвитку й зменшити дію реальних загроз, які $\epsilon$ постійними супутниками будь-якої економічної системи.

Враховуючи, що економічна безпека формування інвестиційного потенціалу аграрного підприємства є системою, необхідно розглянути сутність терміну «система». Система - це засіб, за допомогою якого відбувається процес вирішення проблем» [5].

П. Саблук вважає, що «... це організоване чи складне ціле, зібрання або сполучення речей чи частин, що утворюють складне чи єдине ціле» [6].

Ю. Лузан під системою розумів «... сукупність об'єктів, поєднаних якоюсь формою постійної взаємодії чи взаємозалежності 3 метою виконання певних функцій» [7].

Енциклопедичний словник визначає систему як сукупність (множину) моментів, що, взаємодіючи між собою, утворюють певну цілісність, єдність. Грунтуючись на дослідженнях, здійсненими вищезгаданими та іншими авторами, на наш погляд, економічну безпеку формування інвестиційного потенціалу підприємства слід розгля- дати як відкриту, гнучку, динамічну, складну, кібернетичну та цілескеровану економічну систему, що складається $з$ багатьох підсистем, які самостійно здатні вирішувати різні функціональні завдання. Основою формування такої системи може бути концепція сталого розвитку; концепція Кайдзен; концепція управління вартістю; концепція компетенцій; концепція усунення обмежень; концепція стратегічного управління; концепція перевірки i корегування стратегічних передбачень; концепція управління знаннями; концепція соціальної відповідальності бізнесу.

Основними функціями системи економічної безпеки суб'єктів господарської діяльності можуть бути: забезпечення фінансової стійкості; забезпечення безпеки капіталу та майна підприємства; досягнення конкурентоспроможності та високого рівня економічного потенціалу; досягнення високого рівня менеджменту, оптимальної організаційної структури управління суб'єктами фінансової безпеки галузі; правова захищеність господарської діяльності підприємств господарства [8].

Визначаючи ефективність системи економічної безпеки формування інвестиційного потенціалу аграрного підприємства, необхідно уточнити сутність таких економічних категорій як «потенціал», «інвестиційний потенціал», «ризик», «загроза». В науковій літературі «потенціал» трактують як збірне поняття, яке охоплює такі складові як економічний, фінансовий, трудовий, виробничий, інноваційний інвестиційний потенціали [9]. Це поняття також трактується як сукупність ресурсів, факторів і можливостей. 
На думку А. Мясникова «потенціал» може розглядатися як засоби, запаси, джерела які $є$ у наявності і можуть бути мобілізовані для досягнення певної мети або вирішення будь якого завдання [10].

С й інші трактування цієї категорії. Так, Т. Шебатура [11] визначає цю економічну категорію як систему матеріальних та трудових ресурсів, скерованих на досягнення мети виробництва.

О.В. Ілляшенко, О.В. Жегус трактують як «... сукупність усіх функціонуючих, наявних й альтернативних ресурсів, залучених у сферу виробництва та управління, яка характеризує здатність господарської системи виконувати свої функції з уточненням можливостей виробничих сил для досягнення певного ефекту [12].

Виходячи 3 визначень економічної категорії «потенціал» вищезазначеними дослідниками, у загальному вигляді іiі можна трактувати як сукупність матеріальних і нематеріальних цінностей, виробничих, трудових, фінансових, інформаційних, інфраструктурних та інших ресурсів, які можуть використовуватися у суспільному господарстві для досягнення визначеної мети.

У відповідності до теми наших досліджень необхідно визначити сутність терміну «інвестиційний потенціал». Інвестиційний потенціал $є$ сукупністю усіх видів інвестиційних ресурсів, які можуть залучатися для вирішення екологічних, економічних, соціальних та інших проблем.

Іншими важливими економічними категоріями, які активно впливають на формування інвестиційного потенціалу аграрного підприємства $\epsilon$ ризик та загроза. У їх визначенні серед вчених немає єдності. Одні вчені тлумачать «ризик» як можливість виникнення несприятливої ситуації під час реалізації планів і використання бюджетів підприємства, інші вважають, що ризик $\epsilon$ технічною оцінкою ймовірності невдачі або негативного результату, який виводиться шляхом статистичного опрацювання останніх даних. Отже, економічний ризик - це комбінація події, пов'язаної з діяльністю підприємства, яка, впливаючи на нього, унеможливлює досягнення запланованих цілей та отримання запланованих доходів. Беручи за основу визначення ризику вищезгаданими та іншими авторами, ми визначаємо економічний ризик як результат економічних відносин, що грунтується на невизначеності та ймовірному виникненні непередбачуваних подій у майбутньому, які можуть завдати економічних збитків підприємству та (або) унеможливлять досягнення окреслених ним цілей.

Економічна категорія «загроза» характеризується як сукупність умов i факторів, які створюють небезпеку реалізації економічних інтересів. При цьому «небезпека», на думку багатьох вітчизняних вчених, визначається як конкретна і безпосередня реальна форма проявлення загрози. 3 думкою вище зазначених дослідників слід погодитися, так як відсутність сприятливих умов для зростання сільського господарства породжує ризики та загрози формуванню інвестиційного потенціалу підприємства, що є небезпекою його економічного розвитку як у короткостроковій так і довгостроковій перспективі.

Висновки. В умовах соціальноекономічної кризи та обмежених фінансових можливостей, аграрні підприємства повинні бути націлені на 
отримання та практичного використання інформації щодо організації виробництва на основі кооперації, використання сучасних технологій як джерела збереження енергетичних ресурсів та оптимізації використання трудового потенціалу. Не вирішивши цю проблему та не побудувавши ефективну систему економічної безпеки фо- рмування інвестиційного потенціалу на основі оновленої методології та зміни парадигми розвитку сільського господарства, держава ризикує стати перед загрозою зниження рівня своєї продовольчої безпеки та у найближчі декілька років перетворитись 3 експортера аграрної продукції в імпортера.

\section{Список використаної літератури}

1. Танклевська Н.С. Боровік Л.В., Концептуальні засади удосконалення інвестиційної політики розвитку сільського господарства. Науковий вісник Уэгородського національного університету. Серія Міжнародні економічні відносини та світове господарство. 2019. Вип.26. Ч.1. С. 24-28.

2. Мулір Т.В. Функції венчурного капіталу в контексті фінансової безпеки країни. Економічні науки. Серія «Облік і фінанси». Вип. 9(33). Ч.2. 2012. С.17-26.

3. Петрук О.М., Мошенський С.3. Теорія та практика венчурного фінансування: монографія. Житомир: ПП «Рута». 2008. 248с.

4. Танклевська Н.С., Боровік Л.В. Вплив інвестиційної політики на формування економічного інвестиційного потенціалу сільського господарства. Науковий економічний журнал «Інтелект ХХІ». 2019. №3. С. 121-125.

5. Кардаш О.М. Генезис, суть та значення венчурного капіталу у системі фінансового забезпечення інноваційної діяльності. Зб.наук.праџь «Економічний простір». 2008. №19. С. 198-204.

6. Саблук П.Т., Білорус О.Г., Власов В.І. Глобалізація і продовольство : монографія. Київ: НН ЦІАЕ. 2008. 632с.

7. Лузан Ю.Я. Формування наукової парадигми сучасного розвитку аграрного сектору України. Економіка АПК. 2011. №7. С.22-29.

8. Халімон Т.М. Інформаційні технології як платформа ефективного управління конкурентоспроможністю підприємств. «Економіка. Менеджмент. Бізнес». 2016. №4 (18). C.67-74.

9. Остапчук Д.О. Синергетичний підхід до дослідження інвестиційної безпеки України. Право $і$ безпека. 2012. №5. С. 217-222. URL: http: nbuv.gov.ua/j-pdf Pib_2012_5_50.pdf (дата звернення 20.07.2020) 
10. Мясников А.А. Синергетические эффекты в современной экономике: введение в проблематику. Москва: ЛЕНЕНД, 2011. 160с.

11. Шабатура Т.С. Теоретичні підходи до визначення дефініції «Фінансова безпека підприємства». «Інноваџійна економіка». №9 (35). 2012. C.315-318.

12. Ілляшенко О.В., Жегус О.В. Сутнісне трактування потенціалу як джерела комплексної оцінки рівня розвитку виробничих сил. Економічна стратегія $i$ перспективи розвитку сфери торгівлі та послуг. 2010. Вип.2. С.306-312. 